\title{
Development of a Set of Requirements for the Hardware and Software of LMS Services of the University
}

\author{
https://doi.org/10.3991/ijet.v16i21.25239
}

\author{
Vitaly Zuev, Lazzat Kakisheva, Natalya Denissova, Saule Kumargazhanova( $\left.{ }^{\bowtie}\right)$, \\ Saule Smailova \\ D. Serikbayev East Kazakhstan technical university, Oskemen, Kazakhstan \\ skumargazhanova@gmail.com
}

\begin{abstract}
This article considers the issues of expert research to determine a set of requirements for the hardware and software of the key LMS services of the university. Expert questionnaires have been developed to determine categories, including indicators of the functioning of the University's LMS services. Based on the developed questionnaires, a survey of various user groups was conducted: developers, administrators, teachers and students. Based on the processing results, the final set of requirements for the LMS reference model was determined.
\end{abstract}

Keywords-learning management system, expert assessment, LMS services, online education, distance education, higher education

\section{Introduction}

Open the Due to the pandemic, there has been a dramatic increase in the use of the Learning management system (LMS) at all levels of education. LMS can be defined as an information technology system that provides instructors with the flexibility needed to create, maintain and update information related to courses hosted on the Internet on websites [1]. The LMS should have advanced functionality that includes: designing, sharing, delivering, managing and evaluating learning resources for all categories of users, as shown in work [2). There are many benefits to using LMS in the educational process, including: organization of materials; organization of students' independent work; the ability to develop tests and assignments; the ability to monitor activities; and development of the assessment system [3].

Many researchers have studied the relationship between the satisfaction of different categories of users, mainly learners, teachers and moderators of distance learning systems (LMS), and their interaction with the LMS in distance learning. In the works [411] estimates of the interaction of students and teachers with the LMS (learning environment) are presented, proposals are identified, some platforms, components and factors that form a mixed environment are analyzed so that we can facilitate and optimize learning in order to improve the quality of the teaching process. 
In the course of researching the area of LMS design and construction, three main research directions have been identified: LMS content detailing and assessment [1-4, 5-8,11-14], LMS as a Big Data Source [15-17].

As the review of the above studies shows, the emphasis is on the evaluation of online courses, on the satisfaction of existing LMS, or the LMS is presented as an add-on over different sources. This study is aimed at analyzing the development and construction of LMS, and assessing the requirements for LMS in the context of certain categories of users.

The purpose of this study is to develop a set of requirements for the hardware and software of the University LMS services based on expert research. To conduct the research, a project team was created, which included LMS developers, IT specialists and teachers. Research stages:

Stage 1: formation of a working group of experts from various categories

Stage 2 formation of a preliminary set of requirements by the members of the working group

Stage 3 formation of a preliminary questionnaire for a set of requirements for hardware and software services LMS University

Stage 4: conducting a survey and processing the results

Stage 5 - formation of an intermediate questionnaire

Stage 6: conducting a survey and processing the results

Stage 7 - the formation of the final set of requirements for the hardware and software of LMS services of the university.

\section{Methodology}

To create a model of a set of requirements for the hardware of the LMS services of the university, an expert assessment method was chosen. An expert assessment of the set of requirements for the hardware of the LMS services of the university involves dividing the set of requirements into categories, for groups of experts with different competencies. Requirements are divided into blocks according to the principle of the category of requirements and are presented to the respondent depending on his membership in the expert group. In addition, the coefficient of assessment of expert groups for the same category (block) of requirements is also different.

Six factors were selected as predictors of LMS user satisfaction and identified: groups of respondents, categories of requirements, belonging to categories of requirements, weighting coefficients of assessments by categories of requirements (Table 1).

The survey was carried out online in 2 stages:

1. formation of a preliminary set of requirements for LMS services for inclusion in the expert questionnaire (https://docs.google.com/forms/d/e/1FAIpQLSdKoglJnrKaH HohhLL9vTC3nW6I8ANO8a2x6G6VG9GP5KJbYw/viewform).

2. formation of an expert questionnaire for a set of requirements for LMS services (https://docs.google.com/forms/d/e/1FAIpQLSd6HjujNbxBzOkmIPyICGM0EHnq 8vHVH NU3zHq-4gylwaaQA/viewform). 
Table 1. Table of coefficients

\begin{tabular}{|l|c|c|c|c|c|c|c|}
\hline \multirow{2}{*}{ Expert group } & \multicolumn{7}{|c|}{ Factors (P) } \\
\cline { 2 - 8 } & $\begin{array}{c}\text { Software } \\
\text { and hard- } \\
\text { ware }\end{array}$ & $\begin{array}{c}\text { Control and } \\
\text { monitoring }\end{array}$ & $\begin{array}{c}\text { Course de- } \\
\text { velopment }\end{array}$ & $\begin{array}{c}\text { Learning } \\
\text { manage- } \\
\text { ment }\end{array}$ & $\begin{array}{c}\text { Communi- } \\
\text { cation }\end{array}$ & Usability & $\begin{array}{c}\text { Software and } \\
\text { hardware }\end{array}$ \\
\hline IS developer & 1 & 0,8 & 0,2 & 0,2 & 0,1 & 0,1 & 1 \\
\hline $\begin{array}{l}\text { LMS adminis- } \\
\text { trator }\end{array}$ & 0,8 & 1 & 0,8 & 0,8 & 0,2 & 0,2 & 0,8 \\
\hline Teacher & $\begin{array}{c}\text { Not avail- } \\
\text { able }\end{array}$ & Not available & 0,8 & 0,8 & 0,7 & 0,6 & Not available \\
\hline Student & $\begin{array}{c}\text { Not avail- } \\
\text { able }\end{array}$ & Not available & $\begin{array}{c}\text { Not availa- } \\
\text { ble }\end{array}$ & $\begin{array}{c}\text { Not availa- } \\
\text { ble }\end{array}$ & 0,8 & 0,9 & Not available \\
\hline
\end{tabular}

A preliminary set of requirements, consisting of 63 criteria divided into 6 categories, describing the main criteria for an LMS, is shown in Figure 1.

An interim questionnaire was conducted among the members of the project group in order to determine the preliminary requirements for the expert questionnaire.

A five-point Likert scale was used. The scale ranged from (5: mandatory requirement) to (1: strongly redundant requirement).

The analysis of the results of the intermediate examination made it possible to form the main set of requirements, in accordance with the categories, by excluding two requirements from the list of preliminary ones:

1. Category 5 , requirement 49 ;

2. Category 5 requirement 50 .

having less than $50 \%$ of importance for inclusion in the main set of requirements of the expert questionnaire, falling out of the main spot of the distribution of estimates in Figure 2.

At this stage, 61 main criteria of the model for assessing the set of requirements for the software and hardware of the LMS services of the university were determined.

Based on the main set of requirements, an expert questionnaire was developed with the division of access to the categories of requirements depending on the competence of the expert groups.

The survey was conducted from December 2020 to March 2021 on the basis of the East Kazakhstan Technical University named after D. Serikbayev. The sample of respondents was 673 people, in the following categories:

- LMS administrator of the university - 32;

- teaching staff - 137;

- IS developer - 15;

- student - 489.

The questionnaire was pre-tested for reliability and validity with 23 students of distance learning (3rd year students) of East Kazakhstan Technical University. The results were analyzed to determine reliability using the Cronbach alpha method and received 0.71 , which indicates an acceptable content of the questionnaire. 

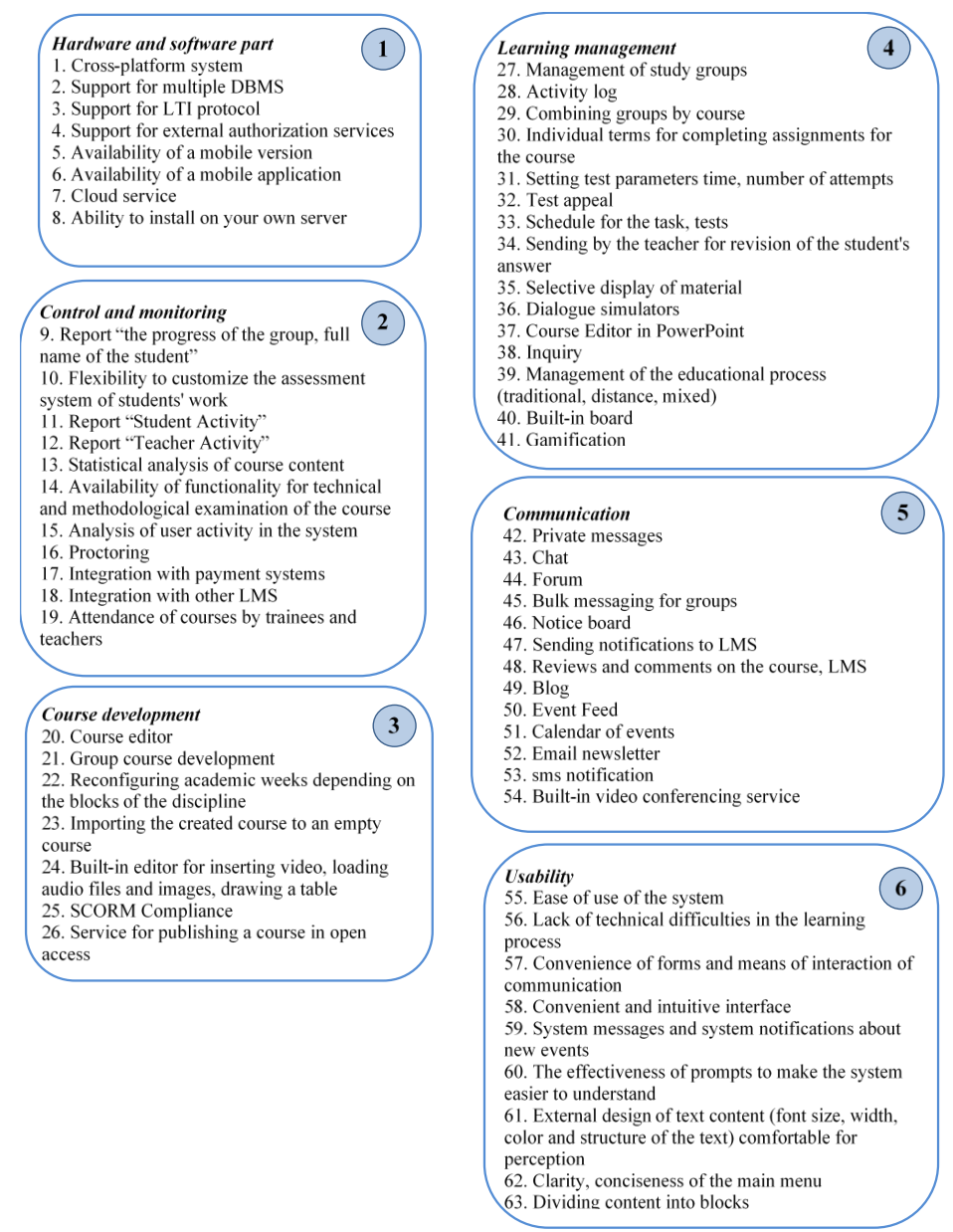

Fig. 1. Preliminary set of requirements

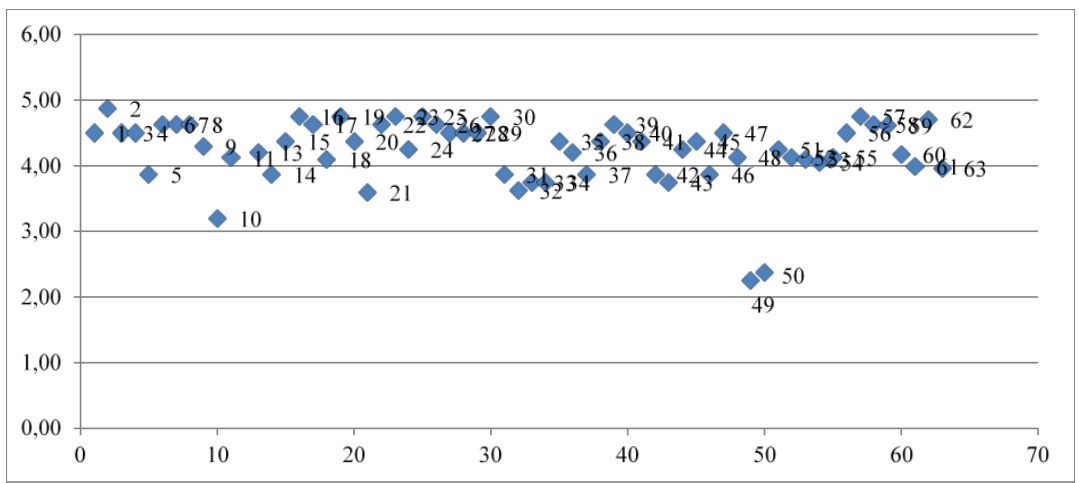

Fig. 2. Distribution of assessments of the requirements of the result of the interim questionnaire 
The experts evaluated the necessary requirements for LMS in points from 0 to 3 (0requirement is absolutely optional, 3-categorically mandatory requirement), taking into account the division of requirements into categories of requirements (Table 1).

The number of experts is denoted by $\mathrm{m}$, and the number of evaluated requirements is denoted by $\mathrm{n}$. The evaluated requirements are designated as $B_{1}, B_{2}, \ldots, B_{n}$. The scores are summarized in a table similar to Table 2.

Table 2. Assessment of requirements in points

\begin{tabular}{|l|c|c|c|c|c|}
\hline \multirow{4}{*}{$\begin{array}{c}\text { Expert } \\
\text { number }\end{array}$} & $\begin{array}{c}\text { Expert group } \\
\text { Q }\end{array}$ & $\begin{array}{c}\text { Category 1 } \\
\mathbf{G}_{1}\end{array}$ & $\begin{array}{c}\text { Category 2 } \\
\mathbf{G}_{2}\end{array}$ & & $\begin{array}{c}\text { Category G } \\
\text { Gg }\end{array}$ \\
\cline { 3 - 6 } & & Requirement 1 $\boldsymbol{B}_{1}$ & Requirement $_{2}$ & $\ldots$ & $\begin{array}{c}\text { Requirement } \\
\text { Bn }\end{array}$ \\
\hline 1 & $1-4$ & $\mathrm{X}_{111}$ & $\mathrm{X}_{121}$ & $\ldots$ & $\mathrm{X}_{1 \mathrm{ng}}$ \\
\hline 2 & $1-4$ & $\mathrm{X}_{211}$ & $\mathrm{X}_{221}$ & $\ldots$ & $\mathrm{X}_{2 \mathrm{ng}}$ \\
\hline$\ldots$ & & $\ldots$ & $\ldots$ & $\ldots$ & $\ldots$ \\
\hline $\mathrm{M}$ & $1-4$ & $\mathrm{X}_{\mathrm{m} 11}$ & $\mathrm{X}_{\mathrm{m} 21}$ & $\ldots$ & $\mathrm{X}_{\mathrm{mng}}$ \\
\hline
\end{tabular}

In Table 2, $X_{i j k}$ is the score in points by the $\mathrm{i}$-th expert of the $\mathrm{j}$-th requirement, the $k$-th category of the requirement. The results obtained according to Table 2 are summarized in Table 3.

Table 3. Fragment of the results

\begin{tabular}{|c|c|c|c|c|c|c|c|c|c|c|c|}
\hline B & $\mathbf{P}$ & $\begin{array}{c}\mathbf{S}_{\mathbf{1}} \\
\underset{\mathbf{q}=\mathbf{1}}{\mathbf{B}_{\mathbf{q}} / \mathbf{n}},\end{array}$ & $\begin{array}{c}\mathbf{S}_{\mathbf{2}} \\
\sum \mathbf{B}_{\mathbf{q}} / \mathbf{n}, \\
\mathbf{q}=\mathbf{2}\end{array}$ & $\begin{array}{c}\mathbf{S}_{\mathbf{3}} \\
\sum \mathbf{B}_{\mathbf{q}} / \mathbf{n}, \\
\mathbf{q}=\mathbf{3}\end{array}$ & $\begin{array}{c}\mathbf{S}_{4} \\
\sum \mathbf{B}_{\mathbf{q}} / \mathbf{n}, \\
\mathbf{q}=\mathbf{4}\end{array}$ & $\begin{array}{c}D_{1} \\
S_{1} . \\
Y_{q k}, \\
q=1\end{array}$ & $\begin{array}{c}\mathbf{D}_{2} \\
S_{2} . \\
Y_{q k}, \\
\mathrm{q}=2\end{array}$ & $\begin{array}{c}D_{3} \\
S_{3} . \\
Y_{q k}, \\
\mathrm{q}=3\end{array}$ & $\begin{array}{c}\mathrm{D}_{4} \\
S_{4} \\
Y_{q k}, \\
\mathrm{q}=4\end{array}$ & $\sum^{\mathbf{T}} D$ & $\begin{array}{c}\mathbf{R} \\
T / Y_{k}\end{array}$ \\
\hline 1 & 1 & 2,3 & 2,0 & & & 2,3 & 1,6 & & & 3,9 & 2,2 \\
\hline 2 & 1 & 2,3 & 1,7 & & & 2,3 & 1,4 & & & 3,7 & 2,1 \\
\hline 3 & 1 & 1,7 & 2,0 & & & 1,7 & 1,6 & & & 3,3 & 1,8 \\
\hline & & & & & & & & & & & \\
\hline 60 & 6 & 3,0 & 2,6 & 3,0 & 2,5 & 0,3 & 0,5 & 1,8 & 2,3 & 4,9 & 2,7 \\
\hline 61 & 6 & 3,0 & 2,6 & 2,5 & 2,7 & 0,3 & 0,5 & 1,5 & 2,4 & 4,7 & 2,6 \\
\hline
\end{tabular}

Where: S (1-4) - average values of assessments on demand (B), by a group of experts q (1-4); D (1-4) - the product of the average values of the estimates S (1-4) on demand (B), by a group of experts q (1-4) by the expert's coefficient q (1-4) of the factor P (1$6)$; $T$ is the sum of the products $D(1-4)$ of the average values of the estimates $S(1-4)$ on demand (B), by a group of experts q (1-4) by the expert's coefficient q (1-4) of the factor $\mathrm{P}(1-6)$; $\mathrm{R}$ is the effective assessment of the requirement as a quotient of the sum of the products $\mathrm{T}$ by the sum of the coefficients of all expert groups by factor $\mathrm{P}(1-6)$.

The analysis of the examination results made it possible to form a set of requirements for the hardware and software of the LMS services of the university (Figure 3), in accordance with the categories, by excluding five requirements from the list (Figure 1): 
1. Category 2, requirement 17 ;

2. Category 3 , requirement 25 ;

3. Category 3, requirement 26 ;

4. Category 4, requirement 37 ;

5. Category 4, requirement 41 ;

6. Category 5, requirement 51;

having less than $70 \%$ of importance, falling out of the main spot of the distribution of estimates.
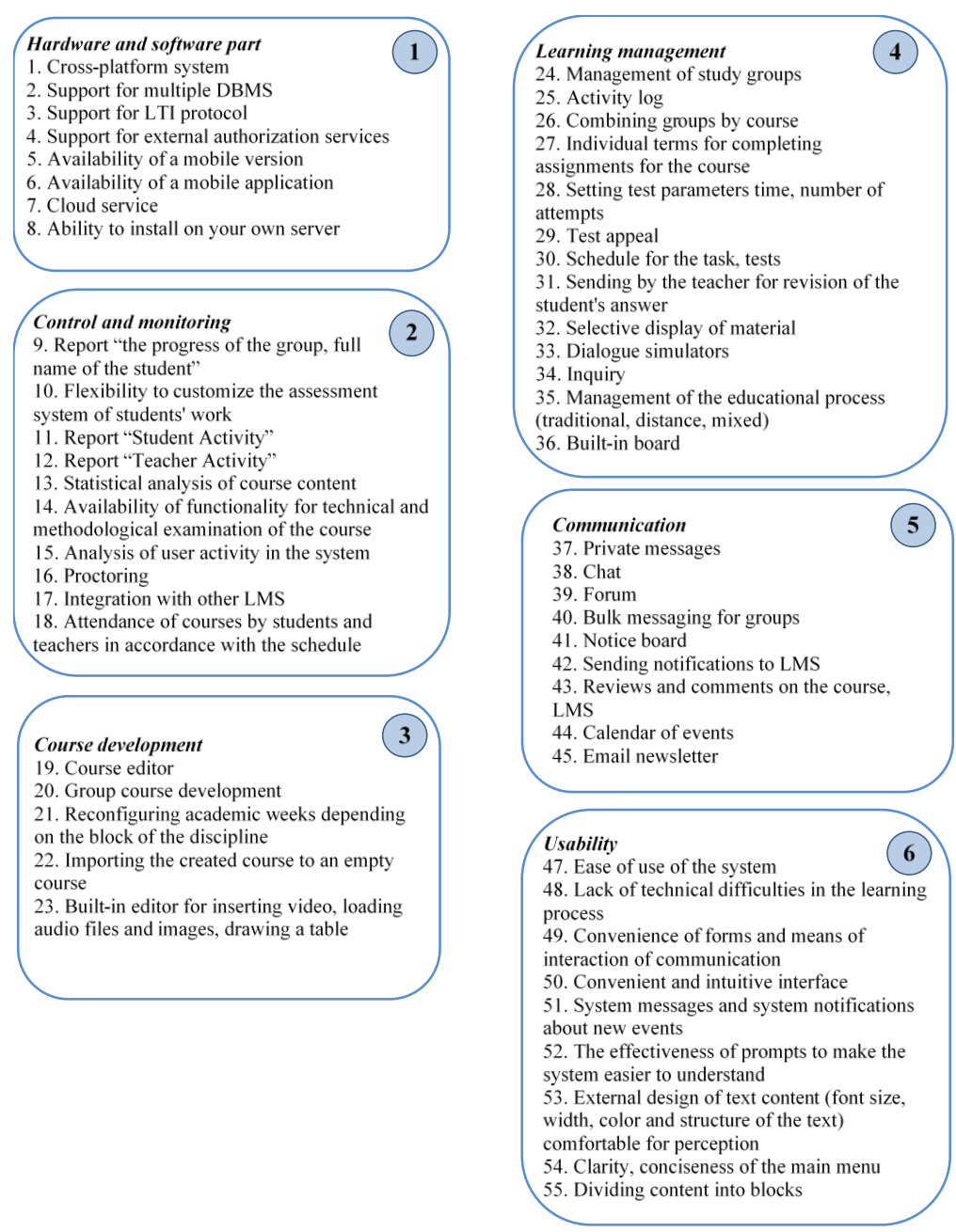

Fig. 3. Final set of requirements for LMS services

The formed criteria based on an expert survey reflect the basic requirements for the hardware and software of the University's LMS services. 


\section{Conclusion}

The research carried out improves the quality of e-learning through multivariate analysis.

The research was carried out in several stages. The initial survey was conducted among the members of the project team, in order to determine a preliminary set of requirements for LMS services for inclusion in the expert questionnaire. The next stage of the questionnaire was carried out among 4 groups of experts in order to determine the main requirements and exclude minor requirements for evaluating the services of the LMS of the university. As a result, the final set of requirements for the hardware and software services of the reference LMS was obtained, which allows assessing the functionality of existing systems.

The results of this study will improve LMS services by providing different categories of users with a more efficient and demanded set of services. In particular, a set of requirements for the hardware and software of LMS services of the university was determined on the basis of expert research, including 55 criteria in 6 categories ("Software and hardware part", "Control and monitoring", "Development of courses", "Learning management", "Communication", "Usability").

\section{Acknowledgment}

The study is carried out within the framework of the project funded by the Ministry of Education and Science of the Republic of Kazakhstan AP08856846 "Methodology for creating a liberal model of On-Line education for higher educational institutions of the Republic of Kazakhstan".

\section{$5 \quad$ References}

[1] Ghazal S. Aldowah H. Umar I. Bervell B. (2018). Acceptance and satisfaction of learning management system enabled blended learning based on a modified DeLone-McLean information system success model.International Journal of Information Technology Project Management, 9(3), 52-71. https://doi.org/10.4018/ijitpm.2018070104

[2] Luo T. Murray A. Crompton H. (2017). Designing authentic learning activities to train preservice teachers about teaching Online.International Review of Research in Open and Distributed Learning, 18(7), 141-157. https://doi.org/10.19173/irrodl.v18i7.3037

[3] Snytnikova, N. (2016, April). Using a Learning Management System in the Course of English for University Students. CSEDU, (1), 531-538. https://doi.org/10.5220/000591 $\underline{3905310538}$

[4] Biggs, M. J. G., Simpson, C., \& Walker, S. L. (2006). Student perceptions of learning environments. Academic Exchange Quarterly, 10, 182-186.

[5] Herbert, M. (2006). Staying the course: A study in online student satisfaction and retention. Online Journal of Distance Learning Administration, 9(4), 1-13.

[6] Jung, I., Choi, S., Lim, C., \& Leem, J. (2002). Effects of different types of interaction on learning achievement, satisfaction and participation in Web-based instruction. Innovations 
in Education and Teaching International, 39, 153-162. https://doi.org/10.1080/147032 90252934603

[7] Kelsey, D. K., \& D'Souza, A. (2004). Student motivation for learning at a distance: Does interaction matter? Online Journal of Distance Learning Administration, 7(2), 1-10. Retrieved October 20, 2005 from http://www.westga.edu/ distance/ojdla/summer72/kelsey72.html

[8] Müller, T. (2008). Persistence of women in online degree-completion programs. International Review of Research in Open and Distance Learning, 9(2), 1-18.

[9] Sahin, I. (2007). Predicting student satisfaction in distance education and learning environments. Turkish Online Journal of Distance Education, 8(2), 113-119.

[10] Stein, D., Wanstreet, E. C., Calvin, J., Overtoom, C., \& Wheaton, E. J. (2005). Bridging the transactional distance gap in online learning environments. American Journal of Distance Education, 19(2), 105-118.

[11] Swan, K. (2003). Learning effectiveness: What the research tells us. In J. Bourne \& J. Moore (Eds.), Elements of quality online education, practice and direction (pp. 13-45). Needham, MA: Sloan Center for Online Education.

[12] Huanhuan Wang, Ahmed Tlili, James D. Lehman, Hang Lu \& Ronghuai Huang (2021). Investigating feedback implemented by instructors to support online competency-based learning (CBL): a multiple case study. International Journal of Educational Technology in Higher Education, 18, 5 (2021). https://doi.org/10.1186/s41239-021-00241-6

[13] Van Wart, M., Ni, A., Medina, P. et al. Integrating students' perspectives about online learning: a hierarchy of factors. Int J Educ Technol High Educ 17, 53 (2020). https://doi.org/ 10.1186/s41239-020-00229-8

[14] Ray, J. A. (2009). An investigation of online course management systems in higher education: Platform selection, faculty training, and instructional quality. International Journal of Information and Communication Technology Education (IJICTE), 5(2), 46-59. https://doi.org/10.4018/jicte.2009040105

[15] Maria Ijaz Baig, Liyana Shuib \& Elaheh Yadegaridehkordi (2021) E-learning adoption in higher education: A review. Information Development, 2021. https://doi.org/10.1177/0266 6669211008224

[16] Banica Logica, Radulescu Magdalena (2015) Using Big Data in the Academic Environment. Procedia Economics and Finance 33, 277-286. https://doi.org/10.1016/s2212-5671(15) $\underline{01712-8}$

[17] Vidal Alonso, Olga Arranz (2016) Big Data \& eLearning: A Binomial to the Future of the Knowledge Society. International Journal of Interactive Multimedia and Artificial Intelligence 3(6), 29-33. https://doi.org/10.9781/ijimai.2016.364

[18] Viktor Shurygin, Anna Berestova, Tatiana Litvinova, Eugeny Kolpak, Alesya Nureyeva (2021) Universal Models and Platforms in E-Learning. International Journal of Emerging Technologies in Learning (iJET) Vol. 16, No. 09, 63-75. https://doi.org/10.3991/ijet. v16i09.19697

[19] Arshi Naim, Fahad Alahmari (2020) Reference Model of E-learning and Quality to Establish Interoperability in Higher Education Systems. International Journal of Emerging Technologies in Learning (iJET) Vol. 15, No. 02, 15-28. https://doi.org/10.3991/ijet.v15i02.11605

[20] Rizky Firmansyah, Dhika Maha Putri, Mochammad Galih Satriyo Wicaksono, Sheila Febriani Putri, Ahmad Arif Widianto, Mohd Rizal Palil (2021) Educational Transformation: An Evaluation of Online Learning Due to COVID-19. International Journal of Emerging Technologies in Learning (iJET) 16, No. 07, 61-76. https://doi.org/10.3991/ijet.v16i07.21201 
[21] Yaremko S.A., Nikolina I.I., Kuzmina E.M., Pugach S.S., Wójcik W., Denissova N., Kozbakova A. (2020) Model of Integral Assessment of Innovation Implementation in Higher Educational Establishments. International Journal of Electronics and Telecommunications, Volume 66, Issue 3, 417-423. https://doi.org/10.24425/ijet.2020.131894

[22] Saule.Kumargazhanova, Aizhan Erulanova, Gulzhan Soltan, Laura Suleimenova, Gulnaz Zhomartkyzy (2018) System of indicators for monitoring the activities of an educational institution. Ural Symposium on Biomedical Engineering, Radioelectronics and Information Technology (USBEREIT), 179-182. https://doi.org/10.1109/usbereit.2018.8384580

[23] S. Kumargazhanova, G. Zhomartkyzy, G.Soltan, L. Suleymenova (2019) Analytical monitoring model of educational system. Proceedings of the 5th International Conference on Engineering and MIS 2019 (ICEMIS '19), ACM. - Nur-Sultan, Kazakhstan, 1-6. https://doi.org/10.1145/3330431.3330445

\section{Authors}

Vitaly Zuev, Head of the Department of Information Technologies of D. Serikbayev EKTU (Email: VZuev@ektu.kz).

Lazzat Kakisheva, highly qualified engineer of the Department of Information Technologies of D. Serikbayev EKTU (Email: lvzzat.kakisheva@ektu.kz).

Natalya Denissova, Candidate of Physical and Mathematical Sciences, Associate Professor, Vice-Rector for Research and Digitalization of D. Serikbayev EKTU (Email: NDenisova@ektu.kz).

Saule Kumargazhanova, Candidate of Technical Sciences, Associate Professor, Dean of the School of Information Technologies and Intelligent Systems of D. Serikbayev EKTU.

Saule Smailova, PhD, Associate Professor of the School of Information Technologies and Intelligent Systems of D. Serikbayev EKTU (Email: ssmailova@ektu.kz).

Article submitted 2021-07-04. Resubmitted 2021-08-10. Final acceptance 2021-08-13. Final version published as submitted by the authors. 